\title{
Effect of short photoperiodic cycles on male genital tract and testicular parameters in male goats (Capra hircus)
}

\author{
JA Delgadillo 1, MT Hochereau-de Reviers 2, \\ A Daveau ${ }^{3}, \mathrm{P}$ Chemineau ${ }^{3 *}$ \\ 1 Universidad Autónoma Agraria Antonio Narro, Carretera a Santa Fé y Periférico, \\ Torreón, Coahuila, Mexico; \\ 2 INRA, URA CNRS 1291, 37380 Nouzilly; \\ ${ }^{3}$ INRA, neuroendocrinologie sexuelle, physiologie de la reproduction \\ des mammifères domestiques, 37380 Nouzilly, France
}

(Received 26 January 1995; accepted 7 July 1995)

\begin{abstract}
Summary - This study was performed in adult male goats in which seasonal variations were abolished by rapid alternations of long days and short days. These treatments have been shown previously to prevent seasonal changes in the hypothalamo-pituitary axis and to maintain testis weight and sperm production at a high level. The experimental groups were exposed for 3 years to an alternation of either a 1 month short ( $16 \mathrm{~h}$ dark; $8 \mathrm{~h}$ light) and 1 month long (16 L; $8 \mathrm{D}$ ) photoperiod ( 2 month cycle; $n=5$ ) or of a 2 month short and 2 month long photoperiod ( 4 month cycle; $n=4$ ). The control groups were maintained in natural photoperiodic conditions $\left(45^{\circ} \mathrm{N}\right)$ and goats were slaughtered in the non-breeding season (end of April RS; $n=5$ ) at the same period as light-treated bucks, or in the breeding season (end of September BS; $n=6$ ). The total weight of the testes, the length and mean diameter of the seminiferous tubules of light-treated goats were similar to those in the breeding season, and higher than those in the non-breeding season. The total number of $A_{0}$ spermatogonia was increased by light treatments as compared to control goats in the breeding and non-breeding season. The daily production of $A_{1}$ spermatogonia, leptonene primary spermatocytes and round spermatids in light-treated goats was maintained at the peak breeding season level. The intra-testicular concentration of testosterone, total volumes of intertubular tissue and of Leydig cells, and the number of Leydig cells per testis did not differ between groups. Although the mean cross-sectional area of Leydig cells in light-treated goats was similar to this area in non-breeding season goats, it was significantly lower than that of breeding season goats. In conclusion, the rapid alternation of short and long days allowed an increase in all the germ cells from the $A_{0}$ spermatogonia onwards, which was responsible for the maintenance of high spermatogenetic activity of light-treated goats.
\end{abstract}

testis / buck / photoperiod / spermatogenesis / Leydig cells

* Correspondence and reprints 
Résumé - Effet des traitements photopériodiques sur le tractus génital et les paramètres testiculaires chez le bouc (Capra hircus). Des nythmes photopériodiques accélérés pendant 3 années consécutives abolissent les variations saisonnières de l'activité sexuelle chez les boucs. Ces traitements atténuent les changements saisonniers de l'activité de l'axe hypothalamus-hypophyse-testicule et permettent de maintenir une activité spermatogénétique élevée. Pour étudier l'effet de ces traitements photopériodiques sur les paramètres testiculaires, 4 groupes de boucs de race Alpine et Saanen sont utilisés. Les groupes expérimentaux sont soumis à une alternance de 1 mois de jours longs $(16 \mathrm{~h}$ de lumière ; 8 h d'obscurité) et de 1 mois de jours courts ( $8 \mathrm{~L}: 160 ;$ lot : $2-\mathrm{mo} ; \mathrm{n}=5$ ) ou 2 mois de jours longs et 2 mois de jours courts (lot: 4-mo; $n=4$ ). Les groupes témoins ont été placés sous les variations naturelles de la photopériode ( $45^{\circ}$ latitude nord). Les 2 lots expérimentaux et un groupe témoin (lot : repos sexuel RS ; $\mathrm{n}=5$ ) sont abattus fin avril. L'autre lot témoin est abattu fin septembre (lot: activité sexuelle $B S ; \mathrm{n}=6$ ). Le poids testiculaire, la longueur et le diamètre des tubes séminifères sont similaires pour les animaux des 2 lots expérimentaux et du lot BS, mais supérieurs à ceux des boucs du lot $R S$. Le nombre total de spermatogonies $A_{0}$ est augmenté dans les lots traités par rapport aux 2 lots témoins. La production quotidienne de spermatogonies $A_{1}$, de spermatocytes primaires leptotènes et de spermatides rondes dans les lots traités est semblable à celle observée dans le groupe BS. La concentration intratesticulaire de testostérone, le volume total du tissu intertubulaire et celui des cellules de Leydig, et le nombre de cellules de Leydig par testicule ne sont pas différents entre lots. La surface de section des cellules de Leydig est identique entre les 2 lots traités et le lot $R S$ mais inférieure dans le lot BS. II est conclu que l'alternance rapide entre les jours longs et les jours courts augmente le nombre de cellules de la lignée germinale depuis les spermatogonies $A_{0}$ souches de réserve et permet le maintien d'une activité spermatogénétique élevée chez les boucs traités.

testicule / bouc / photopériode / spermatogenèse / cellules de Leydig

\section{INTRODUCTION}

Alpine and Saanen male goats naturally exhibit large seasonal variations in $\mathrm{LH}$ and testosterone secretion, testis weight, quantitative and qualitative sperm production (Delgadillo and Chemineau, 1992; Delgadillo et al, 1991, 1992). Maximum plasma levels of both hormones and sperm production occur in autumn and winter (Saumande and Rouger, 1972; Delgadillo et al, 1991; Delgadillo and Chemineau, 1992), and these seasonal variations are mainly entrained by photoperiodic changes (Branca and Cappai, 1989; Delgadillo et al, 1991; Delgadillo and Chemineau, 1992).

In male sheep and goats subjected to rapid photoperiodic changes, the seasonal fluctuations in $\mathrm{LH}$ and testosterone release were abolished and maximum plasma $\mathrm{LH}$ and testosterone concentrations in lighttreated males never reached those observed in control animals during the breeding season (Almeida and Pelletier, 1988; Delgadillo and Chemineau, 1992). These rapid photoperiodic alternations prevented the negative feedback effect of high testosterone secretion and therefore maintained high testis weight and sperm production (Almeida and Pelletier, 1988; Delgadillo and Chemineau, 1992). Indeed, light treatments allowed experimental groups to produce more spermatozoa per ejaculate, even during the natural breeding season of the control bucks. The total number of spermatozoa per ejaculate in a second experimental year was higher in the 2 and 4 month groups than in the controls (Delgadillo et al, 1991). This difference was also recorded at the end of the third experimental year during the daily sperm output test (Delgadillo et al, 1993).

The aim of this study was to determine the effects of 2 month and 4 month light cycles on genital tract, seminiferous tubule and Leydig cell parameters and on intra- 
testicular testosterone concentration and compare them with testes of bucks examined during and out of the breeding season.

\section{MATERIALS AND METHODS}

\section{Animals}

Nine adult Alpine and Saanen male goats were submitted over 3 consecutive years to rapid photoperiodic changes. They were the same males as described in Delgadillo et al (1992, 1993). The first group, 2 months ( 2 -mo, $n=5$ animals), was subjected to 1 month of long days (16 $\mathrm{h}$ of light/8 $\mathrm{h}$ of darkness) and to 1 month of short days ( $8 \mathrm{~h}$ of light/16 $\mathrm{h}$ of darkness). The second group, 4 months (4-mo, $n=4)$, was subjected to alternations of 2 months of long and 2 months of short days. They were compared with 2 groups of male goats subjected to natural photoperiodic changes, taken either at the end of April $(n=5)$ during the non-breeding resting season (RS) or during the breeding season (BS) at the end of September $(n=6)$.

Goats of 2-mo, 4-mo and RS groups were slaughtered at the end of the third experimental year (end of April, at the end of a short-day period) and BS goats were slaughtered in October. Immediately after slaughter, testes, epididymis and seminal vesicles were weighed. A small sample (1-2 $\mathrm{cm}^{3}$ ) of one testis per buck was fixed in Bouin-Hollande solution and processed for histological observation. The second testis was kept frozen at $-20^{\circ} \mathrm{C}$ until assayed for intra-testicular testosterone.

\section{Histology}

Histological analysis was performed on $10 \mu \mathrm{m}$ thick sections as previously described (Hochereau-de-Reviers et al, 1992). Seminiferous tubule (volume, total length, diameter germinal and Sertoli cell number) and intertubular tissue (total volume, Leydig cell number and volume) parameters were determined. The relative volumes of intertubular tissue and seminiferous tubules in testicular parenchyma, and of Leydig cells and blood and lymph vessels in intertubular tissue were determined with a 25-point ocular integrator on 20 fields per animal at magnifications $\times 200$ and 800 , respectively. The mean cross-sectional area of seminiferous tubules, Sertoli cell nuclei and Leydig cells was measured with a planimeter program (Apple software) respectively at magnifications $x 40$ and 1000 respectively. The nuclei of Sertoli, $A_{0}$ and $A_{1}$ spermatogonia (stages 6 to 1 according to Ortavant, 1959), leptotene primary spermatocytes (stages 1 and 2) and round spermatids (stages 6-1) were counted on 10 cross-sections of seminiferous tubules per animal. The number of Sertoli cells and germ cells per section was corrected for the nuclear size and section thickness as described by Abercrombie (1946), assuming that nuclei were spherical in nature. The total length of the seminiferous tubules per testis was then calculated according to the equation of Attal and Courot (1963). The total numbers of Sertoli, germinal and Leydig cells were calculated as described in Hochereau-de-Reviers et al (1992), and the daily production of germ cells was then calculated from their total numbers per testis divided by the mean duration of the seminiferous epithelium cycle, ie $9.8 \mathrm{~d}$ in the male goat (Derashri et al, 1992).

\section{Intra-testicular testosterone content}

To measure testosterone, a sample (ca $4.3 \mathrm{~g}$ ) of testicular parenchyma was homogenized in 12 $\mathrm{ml}$ distilled water. The homogenates were incubated for $30 \mathrm{~min}$ at ambient temperature with $2000 \mathrm{cpm}\left[{ }^{3} \mathrm{H}\right]$ testosterone to estimate the yield of testosterone. Steroids were extracted in $5 \mathrm{vol}$ cyclohexane/ethyl acetate $(1: 1, \mathrm{vol} / \mathrm{vol})$ and testosterone levels were measured by radioimmunoassay as previously described (Delgadillo and Chemineau, 1992).

\section{Statistics}

Testicular and epididymal weights were compared by Student's $t$-test. Histological parameters and intra-testicular testosterone content were compared either by analysis of variance or by Mann-Whitney non-parametric $U$-test (Statview and Superanova softwares, Abacus concept, CA, USA). 


\section{RESULTS}

\section{Genital tract and intra-testicular testosterone content}

Testis weights did not differ between 2-mo, 4-mo and BS goats and equalled, on average, $174 \mathrm{~g}$ (table I). However, they were significantly heavier $(117 \mathrm{~g})$ than those from RS goats, $+62 \%(P<0.01),+55 \%(P<0.05)$ and $+28 \%(P<0.05)$ for $2-\mathrm{mo}, 4-\mathrm{mo}$ and $B S$, respectively. The mean epididymal weight of light-treated goats (2-mo and 4mo groups combined) was significantly heavier than those maintained in natural light conditions (BS and RS groups combined) $(+24 \% ; P<0.05)$. Seminal vesicles weight, mean intra-testicular testosterone concentrations and mean total testosterone content did not differ significantly between groups, but the variation coefficient was higher in RS and BS bucks than in lighttreated animals.

\section{Intertubular tissue parameters}

The total volume of intertubular tissue, of blood vessels and lymph, of Leydig cells and the total number of Leydig cells per testis did not differ significantly between groups (table II). The cross-sectional area of Leydig cells was higher in BS animals that in RS, 2-mo and 4-mo groups $(+39,+20$ and $30 \%$, respectively) $(P<0.05)$.

Table I. Testicular, epididymal, seminal vesicular weight and intra-testicular concentration of testosterone of Alpine and Saanen male goats subjected to 2 month (2-mo) and 4 month (4-mo) light cycles or to natural photoperiodic changes and slaughtered during breeding (BS) or resting (RS) seasons $(m \pm s d)$.

\begin{tabular}{|c|c|c|c|c|}
\hline Parameter & $2-m o$ & 4-mo & $B S$ & $R S$ \\
\hline Number of goats & 5 & 4 & 6 & 5 \\
\hline Mean testicular weight $(\mathrm{g})$ & $190 \pm 44^{a}$ & $181 \pm 44^{a}$ & $150 \pm 52^{a}$ & $117 \pm 5^{b}$ \\
\hline Mean epididymal weight $(\mathrm{g})$ & $38.1 \pm 6.3^{a}$ & $33.1 \pm 7.5^{\mathrm{a}}$ & $28.7 \pm 9.6^{b}$ & $29.2 \pm 2.6^{b}$ \\
\hline $\begin{array}{l}\text { Total seminal vesicular } \\
\text { weight }(\mathrm{g})\end{array}$ & $16.3 \pm 3.6^{a}$ & $10.8 \pm 2.2^{\mathrm{a}}$ & $18.5 \pm 5.3^{a}$ & $14.9 \pm 4.4^{\mathrm{a}}$ \\
\hline $\begin{array}{l}\text { Intra-testicular concentration } \\
\text { of testosterone ( } \mathrm{ng} / \mathrm{g} \text { tissue) }\end{array}$ & $44.9 \pm 19.0^{a}$ & $53.9 \pm 14.2^{\mathrm{a}}$ & $104.1 \pm 95.2^{\mathrm{a}}$ & $78.1 \pm 67.3^{a}$ \\
\hline Coefficient of variation (\%) & 42 & 26 & 91.5 & 73.6 \\
\hline $\begin{array}{l}\text { Total intra-testicular content } \\
\text { of testosterone ( } \mu \mathrm{g} / \mathrm{testis})\end{array}$ & $8531 \pm 836$ & $9756 \pm 625$ & $15615 \pm 4950$ & $9138 \pm 337$ \\
\hline
\end{tabular}


Table II. Intertubular tissue and Leydig cells parameters of Alpine and Saanen male goats subjected to 2 month (2-mo) and 4 month (4-mo) light cycles or to natural photoperiodic changes and slaughtered during breeding (BS) or resting (RS) seasons $(\mathrm{m} \pm \mathrm{sd})$.

\begin{tabular}{|c|c|c|c|c|}
\hline Parameter & $2-m o$ & $4-m o$ & $B S$ & $R S$ \\
\hline Number of goats & 5 & 4 & 6 & 5 \\
\hline \multicolumn{5}{|l|}{ Volume/testis } \\
\hline Intertubular tissue $\left(\mathrm{cm}^{3}\right)$ & $31.6 \pm 9.1^{\mathrm{a}}$ & $34.5 \pm 9.4^{\mathrm{a}}$ & $25.0 \pm 12.7^{a}$ & $28.1 \pm 3.1^{\mathrm{a}}$ \\
\hline $\begin{array}{l}\text { Blood and lymph vessels } \\
\text { total volume }\left(\mathrm{cm}^{3}\right)\end{array}$ & $7.8 \pm 2.4^{a}$ & $6.9 \pm 2.4^{a}$ & $5.7 \pm 3.1^{a}$ & $7.0 \pm 1.9^{a}$ \\
\hline \multicolumn{5}{|l|}{ Leydig cells } \\
\hline Total volume/testis $\left(\mathrm{cm}^{3}\right)$ & $0.9 \pm 0.3^{a}$ & $0.8 \pm 0.2^{\mathrm{a}}$ & $0.8 \pm 0.4^{a}$ & $0.9 \pm 0.3^{a}$ \\
\hline Numbers/testis $\left(\times 10^{8}\right)$ & $6.6 \pm 2.4^{a}$ & $7.7 \pm 2.1^{\mathrm{a}}$ & $4.9 \pm 2.4^{a}$ & $8.2 \pm 2.0^{a}$ \\
\hline Cross-sectional area $\left(\mu \mathrm{m}^{2}\right)$ & $43.7 \pm 8.1^{a}$ & $40.3 \pm 6.8^{a}$ & $52.3 \pm 9.5^{b}$ & $37.7 \pm 3.0^{\mathrm{a}}$ \\
\hline
\end{tabular}

For each parameter, numbers with different superscripts differed significantly $(\mathrm{a} \neq \mathrm{b}: P<0.05$ ).

\section{Seminiferous tubules parameters and germ cell parameters (table III, figs 1-4)}

The length of seminiferous tubules per testis was not different between 2-mo, 4-mo and BS groups but it was significantly higher than in RS group $(+36,+38$ and $+34 \%$, respectively) $(P<0.01)$ (table III, figs $1-4)$. The mean diameter of the seminiferous tubules was not different between 2-mo and 4-mo groups as well as between BS and RS groups, but the mean diameter of seminiferous tubules of the 2-mo group was greater than that observed in BS and RS groups ( +13 and $+18 \%$, respectively) $(P<$ 0.01 ). The total number of Sertoli cells per testis (corrected for nuclear size) was similar in animals of all groups (mean $=16 \mathrm{x}$ $\left.10^{8}\right)$. The mean cross-sectional nuclear area of Sertoli cells did not differ significantly between treatments $\left(\right.$ mean $\left.=74.7 \mu \mathrm{m}^{2}\right)$.

The total number of $A_{0}$ spermatogonia per testis was similar in 2-mo and 4-mo animals but was significantly $(P<0.05)$ higher than that of RS and BS animals (+82 and
$+59 \%$, respectively). The daily productions of $A_{1}$ spermatogonia, leptotene primary spermatocytes and round spermatids did not differ between 2-mo, 4-mo and BS groups. They were significantly higher than the values observed in RS groups (A1: $P<0.05$; primary spermatocytes: $P<0.001$; and round spermatids: $P<0.01$ ). By combining the photoperiod-controlled and $B S$ groups, the daily productions of $A_{1}$ spermatogonia was $85 \%$, leptotene primary spermatocytes $125 \%$ and round spermatids $67 \%$ higher than the corresponding productions in RS goats.

\section{DISCUSSION}

The present results showed that in male goats, short light cycles enhanced the total number of germ cells from $A_{0}$ spermatogonia onwards and maintained a high spermatogenetic activity at the end of the 3 experimental years. Such high spermatogenic efficiency observed after 3 years of 

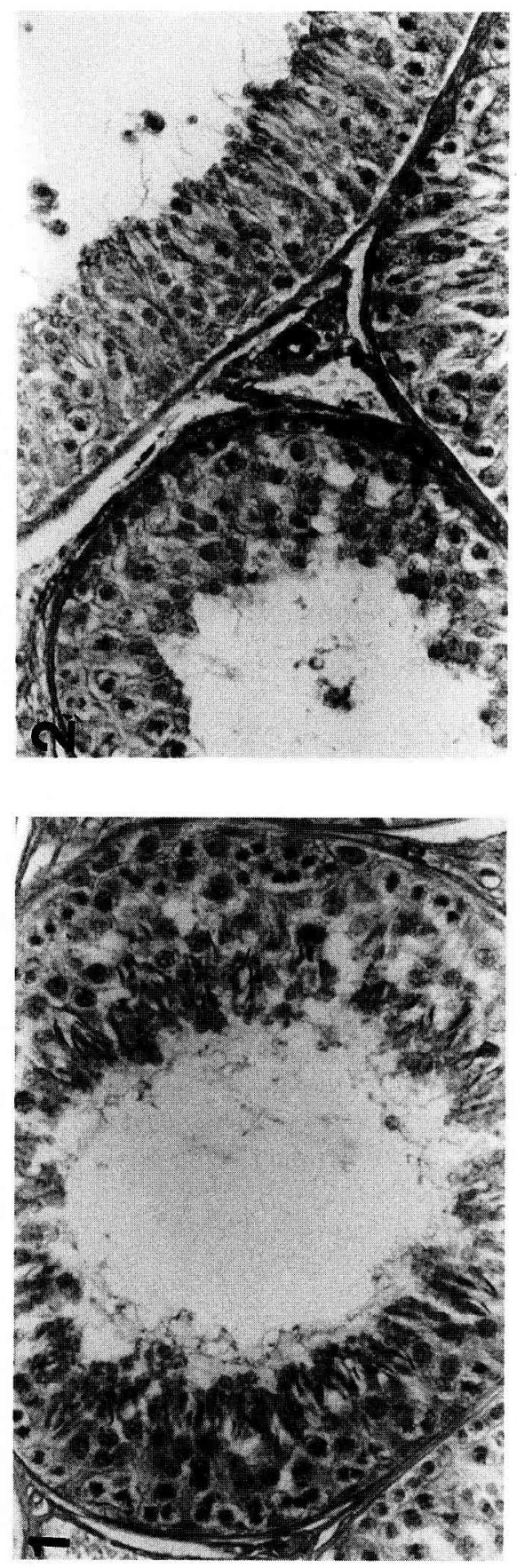

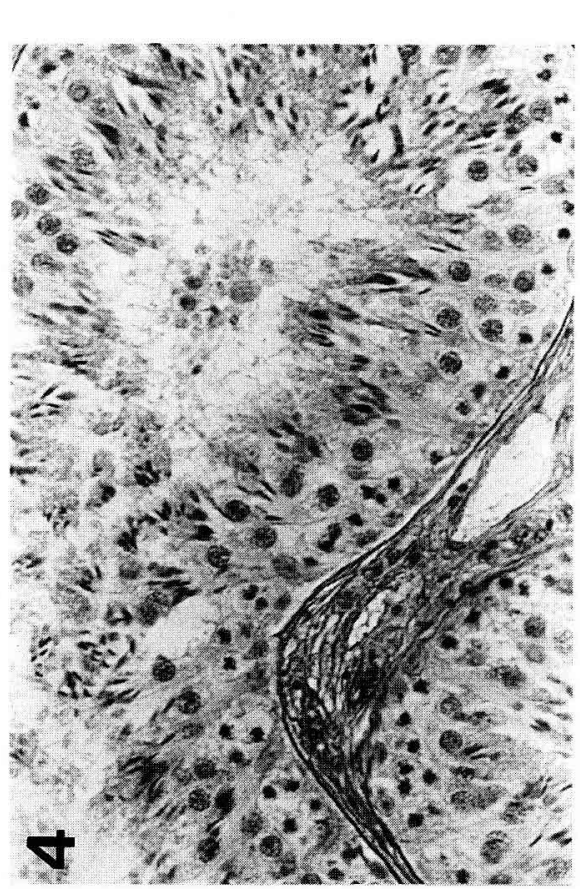

壱 동휴음 टे हैं क N ल 䒕 o. ธํㅇ 혼 过 응 क क 드ㅇㅡㅠ 흥 등 造 苋 눈흥 응 तi 句要 을. 들 융 ه क 苯 专

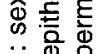
$=$ on

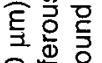

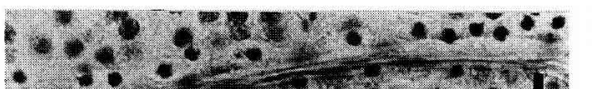

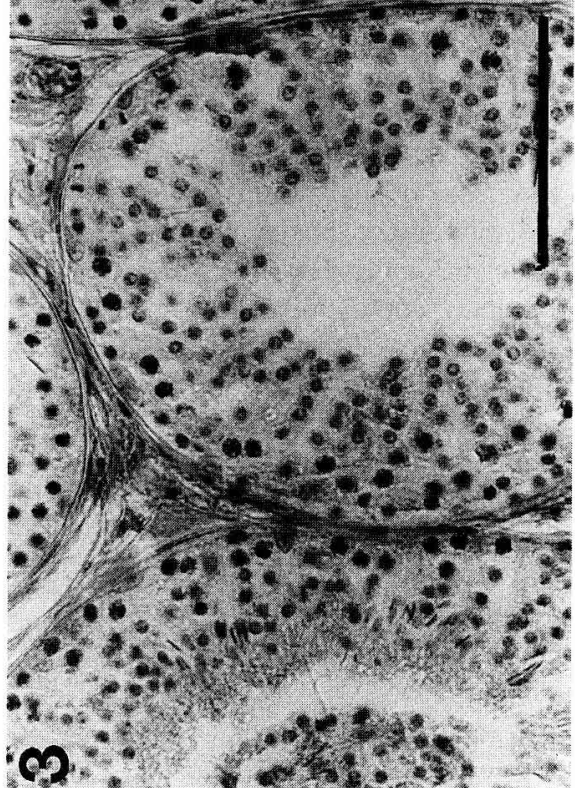
은 $+\frac{\bar{\varepsilon}}{\mathrm{E}}$ II वृ 등 $\frac{\overline{0}}{\mathrm{D}}$ 응 응 $\$$ 要 유 हैं 莳 筃 苋 西 हᄐ용 Ф 을 흥 잉 马 $\frac{1}{\mathrm{I}}$ 은 을 选至 है 过安焉 菏莳菏 通毕 - $8-$ $10 \%$ 㝵密 婂 
Table III. Seminiferous tubules and germ cells parameters of Alpine and Saanen male goats subjected to 2 month $(2-\mathrm{mo})$ and 4 month $(4-\mathrm{mo})$ light cycles or to natural photoperiodic changes and slaughtered during breeding (BS) or resting (RS) seasons $(\mathrm{m} \pm \mathrm{sd})$.

\begin{tabular}{|c|c|c|c|c|}
\hline Parameter & $2-m o$ & 4-mo & $B S$ & RS \\
\hline Number of goats & 5 & 4 & 6 & 5 \\
\hline \multicolumn{5}{|l|}{ Seminiferous tubules } \\
\hline Total volume (ml) & $162 \pm 37$ & $143 \pm 37$ & $127 \pm 40$ & $87 \pm 7$ \\
\hline Length/testis (m) & $2175 \pm 372^{a}$ & $2206 \pm 591^{a}$ & $2136 \pm 664^{a b}$ & $1596 \pm 127^{b}$ \\
\hline Mean diameter $(\mu \mathrm{m})$ & $250 \pm 19^{a}$ & $230 \pm 19$ & $221 \pm 15^{c}$ & $211 \pm 11^{c}$ \\
\hline Lumen mean diameter $(\mu \mathrm{m})$ & $47.8 \pm 7.6$ & $48.3 \pm 5.6$ & $45.0 \pm 5.7$ & $41.8 \pm 4.4$ \\
\hline \multicolumn{5}{|l|}{ Sertoli cells } \\
\hline Total No/testis $\left(\times 10^{8}\right)$ & $17.1 \pm 4.2^{\mathrm{a}}$ & $18.2 \pm 4.9^{a}$ & $15.4 \pm 6.3^{a}$ & $14.0 \pm 2.1^{\mathrm{a}}$ \\
\hline Nuclear area $\left(\mu \mathrm{m}^{2}\right)$ & $70.9 \pm 9.7^{a}$ & $79.1 \pm 7.6^{a}$ & $79.0 \pm 13.0^{a}$ & $69.8 \pm 5.6^{a}$ \\
\hline \multicolumn{5}{|l|}{ Germ cells } \\
\hline \multicolumn{5}{|l|}{ Total number } \\
\hline $\begin{array}{l}\text { A0 spermatogonia/testis } \\
\left(x 0^{8}\right)\end{array}$ & $2.6 \pm 1.2^{a}$ & $2.5 \pm 1.5^{\mathrm{a}}$ & $1.4 \pm 0.7^{b}$ & $1.6 \pm 0.5^{b}$ \\
\hline \multicolumn{5}{|l|}{ Daily production/testis } \\
\hline $\begin{array}{l}\text { A1 spermatogonia }\left(\times 10^{7}\right) \\
\text { Leptotene primary }\end{array}$ & $3.1 \pm 1.5^{a}$ & $2.9 \pm 1.5^{\mathrm{a}}$ & $2.9 \pm 1.3^{a}$ & $1.6 \pm 0.2^{b}$ \\
\hline spermatocytes $\left(\times 10^{9}\right)$ & $0.9 \pm 0.2^{\mathrm{a}}$ & $0.9 \pm 0.2^{\mathrm{a}}$ & $0.9 \pm 0.3^{a}$ & $0.4 \pm 0.1^{c}$ \\
\hline Round spermatids (x 109) & $2.3 \pm 0.3^{a}$ & $2.0 \pm 0.6^{a}$ & $2.2 \pm 0.6^{a}$ & $1.3 \pm 0.2^{c}$ \\
\hline
\end{tabular}

For each parameter, numbers with different superscripts differed significantly $(\mathrm{a} \neq \mathrm{b}: P<0.05 ; \mathrm{a} \neq \mathrm{c}: P<0.01)$.

experiment may explain the very high sperm production reported previously in the same bucks treated with light as compared to control bucks (Delgadillo et al, 1992). Indeed, on the ninth consecutive day of semen collection, the mean daily sperm output (DSO) in both light-treated groups (2-mo: $3.68 \pm$ $0.59 \times 109 ; 4-m o 6.25 \pm 0.61 \times 10^{9}$ spermatozoa/d) was significantly higher than the RS group (2.96 $\pm 0.36 \times 10^{9}$ spermatozoa/d; $P<0.05$ ) (Delgadillo et al, 1993). A similar phenomenon was also observed in lle-deFrance rams subjected to short photoperiodic cycles (Pelletier and Almeida, 1987; Chemineau et al, 1988). The major effect of the light treatments was detected in the germinal cells of the seminiferous tubules with quantitative variations of germ cells, the total number of Sertoli cells remaining unaffected. In the light-treated bucks used here, some endocrine parameters are known since these males were blood sampled in various occasions before slaughter (Delgadillo and Chemineau, 1992). One of the main feature of such light-treated males was the consistent modification in the frequency of pulsatile release of $\mathrm{LH}$, because this gonadotrophin activity was driven by rapid photoperiodic changes and not by annual changes as in control males. The 
frequency of LH release was higher most of the year, especially during the rest season when LH pulsatility was low in control males, but in reverse, during the 1 or 2 months of the full breeding season (around September), control males had a higher pulsatility than light-treated males. In the 2-mo group, mean $\mathrm{LH}$ concentrations were similar in long and short days, while, in the 4-mo group, these concentrations were lower in long than in short days. However, these values never reached the $\mathrm{LH}$ levels observed in the BS group (Delgadillo and Chemineau, 1992). Testosterone secretion may also play an important role in such phenomenon. In spite of the absence of differences between groups in the intra-testicular content of testosterone, which was probably due to the very high variability in testosterone concentration and content of BS and RS groups, a tendency towards a lower testosterone concentration in the testes of light-treated bucks as compared to that of control bucks could be detected. In fact, the mean values of plasmatic testosterone concentrations obtained in both treated groups in weekly blood samples over 2 consecutive years (2$\mathrm{mo}: 10.6 \pm 1.8 \mathrm{ng} / \mathrm{ml}$; 4 -mo: $12.0 \pm 1.8$ $\mathrm{ng} / \mathrm{ml}$ ) were significantly lower than those of the BS group (19.4 $\pm 1.5 \mathrm{ng} / \mathrm{ml})(\mathrm{Del}-$ gadillo and Chemineau, 1992). This relatively low LH secretion in light-treated animals, by moderately stimulating the Leydig cells, induced the maintenance of an intermediate cell volume in between breeding season and rest season. This intermediate volume of Leydig cells and the moderate frequency of $\mathrm{LH}$ release determined the moderate testosterone release. This possibly reduced the steroid feedback effect on LH secretion (Pelletier and Almeida, 1987; Almeida and Pelletier, 1988). As a consequence, in light treated-groups, the moderate $\mathrm{LH}$ and testosterone release maintained testicular weight and spermatogenic activity from spermatogonial division to spermiogenesis at the level observed during the natural breeding season.
The cellular characteristics of Leydig cells observed here correspond to those observed in rams subjected to alternating increasing or decreasing 2 month light cycle regimen (Hochereau-de-Reviers et al, 1992) or that observed after 3 month treatments of constant short days (Hochereau-de-Riviers et al, 1985). The resulting moderate and less variable total intra-testicular testosterone content maintained a nearly constant level of stimulation of the seminiferous epithelium (and of the Sertoli cells). This could explain the absence of seasonal depletion of spermatogenesis which normally occurred in the non-breeding season and affected spermatogonial divisions, meiotic processes and spermiogenesis, inducing depletion of sperm production. This relatively constant intra-testicular level of testosterone corresponds to the situation observed during prepubertal testis growth when the stem spermatogonia developed (Monet-Kuntz et al, 1984). In the light-treated bucks, the first step to be stimulated is the stem cell compartment where both $\mathrm{A} 0$ and A1 spermatogonia populations were increased, as observed previously in the light-treated rams (Hochereau-de-Reviers et al, 1985, 1992). Normally during the sexual season, AO spermatogonial population decreased when A1 spermatogonial one increased (Hochereau-de-Reviers et al, $1976,1992)$, probably by differentiation of the $A 0$ into $A 1$ spermatogonia. In addition to a moderate intra-testicular level of testosterone, different factors could be suspected to be modified in this model. FSH was not assayed because of absence of accurate $\mathrm{FSH}$ radioimmunoassay in the goat, but we can suspect that FSH secretion was increased by the treatment. In ram, the passive immunisation against $\beta$-FSH decreased the B2 spermatogonia and the subsequent production of leptotene spermatocytes (Courot et al, 1985). In mice, FSH stimulates the production by Sertoli cells of steel factor (SLF or SCF) which is the ligand of $c$ kit; this factor stimulates the proliferation of 
A spermatogonia in a dose-dependent manner (Rossi et al, 1993). The degradation of $c$-kit is enhanced by TGF $\beta 1$ (de Vos et al, 1993), the secretion of which is negatively regulated in Sertoli cells by FSH (Benhamed et al, 1988). So FSH could control the proliferation of type A spermatogonia by at least 2 mechanisms: increase in SCF secretion and decrease of its ligand degradation. A second set of factors, which could play a role in this mechanism, includes the activins/inhibin (Mather et al, 1992, 1994). During the seasonal cycle, changes in the plasma concentrations of inhibin occurred in parallel with variation in testis weight. The weekly changes in the plasma concentrations of inhibin are positively correlated with the changes in the plasma FSH concentrations during activation or regression of the testis. During full breeding season (maximum testis weight), inhibin exerts a negative feedback on FSH secretion, then a negative correlation is observed between FSH and inhibin (Lincoln and MacNeilly, 1989). In the rat, FSH regulates mRNA of the $\alpha$ - but not $\beta-B$ subunit of inhibin (Krummen et al, 1989). Activin controls the proliferation of rat spermatogonia (Mather and Krummen, 1992; Kaipia et al, 1992, 1994). Furthermore, an activin $\beta$-neutralizing antiserum blocks activin $\beta$-stimulated ${ }^{3} \mathrm{H}$-thymidine incorporation in spermatogonia (Mather et al, 1994). Activin receptors (Act RII) were detected in type A spermatogonia in rodents (Kaipia et al, 1992, 1994).

In conclusion, the rapid alternations of short and long days prevent the regression of the Leydig cells, promote the proliferation of germ cells from AO reserve stem spermatogonia onwards and maintain a high production of spermatids.

\section{ACKNOWLEDGMENTS}

We wish to thank $\mathrm{J}$ Pelletier and $\mathrm{J}$ Thimonier for help with the experimental design of the study;
C Pisselet, C Perreau, F Maurice, B Lebœuf, JL Bonné, D Bernelas and $Y$ Berson for technical assistance; A Boisseau and J Boutin for the care of the animals; and B Malpaux and D Skinner for assistance with preparation of the manuscript.

\section{REFERENCES}

Abercrombie M (1946) Estimation of nuclear population from microtome sections. Anat Rec 94, 238-248

Almeida G, Pelletier J (1988) Abolition of the seasonal testis changes in the île-de-France ram by short light cycles: relationship to luteinizing hormone and testosterone release. Theriogenology 29, 681-691

Attal J, Courot M (1963) Développement testiculaire et établissement de la spermatogenèse chez le taureau. Ann Biol Anim Biochim Biophys 3, 219-241

Benhamed $M$, Cochet $C$, Keramidas $M$, Chauvin MA, Morera AM (1988) Evidence for a FSH-dependent secretion of a receptor reactive transforming growth factor beta-like material by immature Sertoli cells in primary culture. Biochem Biophys Res Commun 154, 1222-1231

Branca A, Cappai P (1989) Osservazionni sul controllo della riproduzione nelle specie caprina: esperienze effetuate in Sardegna. Symp Int 'La riproduzione nei piccolli ruminanti basi fisiologiche e aspetti applicativi' 115-129

Chemineau P, Pelletier J, Guerin $Y$ et al (1988) Photoperiodic and melatonin for the control of seasonal reproduction in sheep and goats. Reprod Nutr Dev $28,409-422$

Courot M, Hochereau-de-Reviers MT, Pisselet C, Kilgour J, Dubois MP, Sairam MR (1985) Effect of passive immunization against ovine $\beta-\mathrm{FSH}$ on spermatogenesis in the ram. In: The Male in Farm Animal Reproduction (EEC meeting) 6-7 October 1983, Nouzilly (France) (M Courot, ed), Martinus Nijhoff Publ, Boston, 75-79

Delgadillo JA, Chemineau P (1992) Abolition of the seasonal release of luteinizing hormone and testosterone in Alpine male goats (Capra hircus) by short photoperiodic cycles. J Reprod Fertil 94, 45-55

Delgadillo JA, Lebœuf B, Chemineau P (1991) Decrease in the seasonatity of sexual behavior and sperm production in bucks by exposure to short photoperiodic cycles. Theriogenology 36, 755-770

Delgadillo JA, Lebœuf $B$, Chemineau $P$ (1992) Abolition of seasonal variations in semen quality and maintenance of sperm fertilizing ability by photoperiodic cycles in goat bucks. Small Ruminant Res 9 , 47-59

Delgadillo JA, Lebœuf B, Chemineau P (1993) Maintenance of sperm production in bucks during a third 
year of short photoperiodic cycles. Reprod Nutr Dev 33, 609-617

Derashri HJ, Bansal KK, Sharma AK, Verma SK (1992) Reproduction in bucks, spermatogenesis, duration of seminiferous epithelial cycle and germ cell degeneration. In: Pre-Conference Proceedings Abstracts of Contributory Papers, Volume I, V Int Conference on Goats, New Delhi, March 2-8, pp 263

De Vos S, Brach MA, Asano Y et al (1993) Transforming growth factor-beta 1 interferes with the proliferationinducing activity of stem cell factor in myelogenous leukemia blasts through functional down-regulation of the c-kit proto-oncogene product. Cancer Res 53 , 3638-3642

Hochereau-de Reviers MT, Loir M, Pelletier J (1976) Seasonal variations in the response of testis and $\mathrm{LH}$ levels to hemicastration of adult rams. J Reprod Ferti) 46, 203-209

Hochereau-de Reviers MT, Perreau C, Lincoln G (1985) Photoperiodic variation of somatic and germ cell populations in the Soay ram testis. J Reprod Fertil 74, 329-334

Hochereau-de Reviers MT, Perreau C, Pisselet C, Pelletier J (1992) Effect of a 2 month light cycle regimen on testicular parameters of adult lle-de-France rams. Microsc Res Tech 20, 268-273

Kaipia A, Penttila TL, Shimasaki S, Ling N, Parvinen M, Toppari J (1992) Expression of inhibin bA and BB, follistatin and activin-A receptor messenger ribonucleic acids in the rat seminiferous epithelium. Endocrinology 131, 2703-2710

Kaipia A, Toppari J, Huhtaniemi J, Paranko J (1994) Sex difference in the action of activin-A on cell proliferation of differenciating rat gonad. Endocrinology $134,2165-2170$

Krummen LA, Toppari J, Kim WH et al (1989) Regulation of testicular inhibin subunit messenger ribonucleic acid levels in vivo: effects of hypohysectomy and selective follicle-stimulating hormone replacement. Endocrinology 125, 1630-1637

Lincoln GA, MacNeilly AS (1989) Inhibin concentration in the peripheral blood of rams during a cycle in testicular activity induced by changes in photoperiod or treatment with melatonin. J Endocrinol 120, R9R13

Mather JP, Krummen LA (1992) Inhibin, activin and growth factors: paracrine regulators of testicular function. In: Spermatogenesis, Fertilization, Contraception: Molecular, Cellular and Endocrine Events in Male Reproduction (E Nieschlag, UF Habenicht, eds), Springer Verlag, Berlin, 169-200

Mather JP, Krummen LA, Robert PE, Gibson V, Mann E, Stocks D (1994) The role of activin, inhibin and follistatin in the regulation of reproduction in the male. In: Frontiers in Endocrinology, Vol 3. Inhibin and Related Proteins (HG Burger, J Findly, D Robertson, F Petraglia, eds), Ares serono symposia Publ, Roma, 223-231

Monet-Kuntz C, Hochereau-de-Reviers MT, Terqui M (1984) Variation in testicular androgen receptors and histology of the lamb testis from birth to puberty. $J$ Reprod Fertil 70, 203-210

Ortavant $R$ (1959) Déroulement et durée du cycle spermatogénétique chez le bélier. Ann Zootech 4, 271321

Pelletier J, Almeida G (1987) Short light cycles induce persistent reproductive activity in île-de-France rams. J Reprod Fertil Supp/34, 215-226

Rossi P, Dolci S, Albanesi C, Grimaldi P, Ricca R, Geremia R (1993) Follicle-stimulating hormone induction of steel factor (SLF) mRNA in mouse Sertoli cells and stimulation of DNA synthesis in spermatogonia by soluble SLF. Dev Biol 155, 68-74

Saumande J, Rouger Y (1972) Variations saisonnières des taux d'androgènes dans le plasma de sang périphérique chez le bouc. CR Acad Sci Paris 274, 89-92 